\title{
LAND CONVERSION FOR SUBURBAN HOUSING: A STUDY OF URBANIZATION AROUND WARSAW AND OLSZTYN, POLAND
}

\author{
ADAM WASILEWSKI AND KRZYSZTOF KRUKOWSKI
}

CEESA Discussion Paper No. 8 | 2002

ISSN 1616-9166

\begin{abstract}
In the 1990's, urban demand for housing land around city-agglomerations increased rapidly. Additionally, the decreasing profitability of agricultural production caused farmers, who are able to freely decide on land turnover, to be interested in land sale for non-agricultural purposes. At the same time, Polish counties received the status of selfgovernments, which then imposed their will upon local economic development. In this way, counties became responsible for land management as well, and started supporting the process of land conversion, perceived as a factor of the above development. Such implications have created the following situation: decentralisation and the extension of private control over land has led to the loss of rural landscapes in Poland, because farmers, county self-governments and rural society in general gain from the conversion of agricultural to housing land. Therefore, field research has been exercised at the county level. For the investigation, two counties, located in regions differentiated by economic growth, were selected. The data were collected through the collection of archival records, documentation review and semi-structured interviews.
\end{abstract}




\section{About the authors}

Adam Wasilewski works as a researcher for the Institute of Agricultural and Food Economics (IAFE), Department of Social and Regional Policy, Warsaw, Poland. His background is in agricultural economics. His research interests are institutional economics, environmental economics and management of rural areas.

Contact: wasilewski@ierigz.waw.p1

Krzysztof Krukowski is a researcher at the University of Warmia and Mazury (UWM), Faculty of Management, Olsztyn, Poland. His background is marketing and management. His research interests are agricultural economics and environmental economics. Contact: kkruk@moskit.uwm.edu.pl

\section{Acknowledgements}

The authors are very grateful for the helpful comments to this paper from Konrad Hagedorn and from the whole CEESA team, especially Thomas Sikor and Antonia Lutteken, who play a special role in many of the ideas here. Particular appreciation goes to Andrzej Kowalski (Director of Institute of Agricultural and Food Economics), Alina Sikorska (Head of the Department of Social and Regional Policy at IAFE) and Danuta Kolodziejczyk (assistant professor at IAFE) for their support and collaboration with the CEESA project. Finally, special thanks are due to the officials and inhabitants of Piaseczno and Stawiguda County for their help during the field research.

CEESA Discussion Papers are reports prepared by members of the CEESA research network or external authors working on similar topics. The papers have received limited reviews. Views and opinions expressed do not necessarily represent those of the CEESA research project. Comments are highly welcome and should be sent directly to the authors.

\section{ISSN 1616-9166}




\section{CONTENTS}

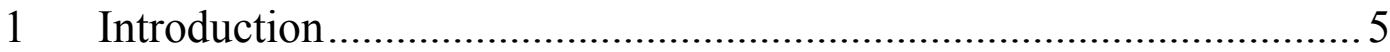

2 Background ......................................................................... 6

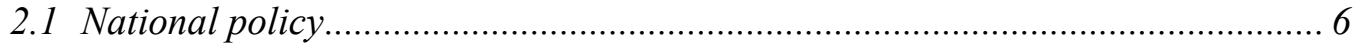

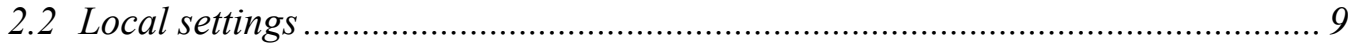

3 Land Conversion in Selected Counties........................................ 14

4 Politics of land conversion..................................................... 15

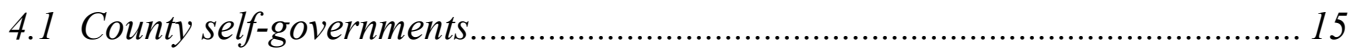

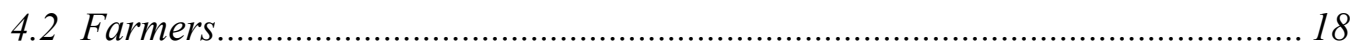

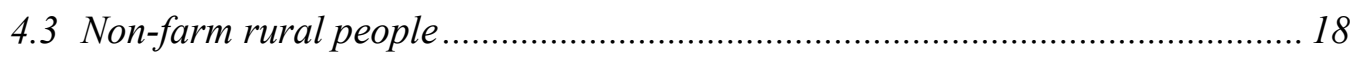

5 Differences in Land Conversion between the Counties ................... 20

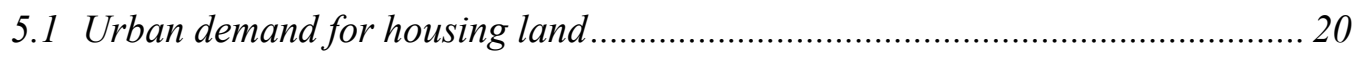

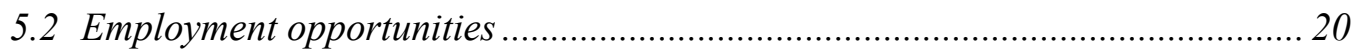

6 Conclusions ....................................................................... 21

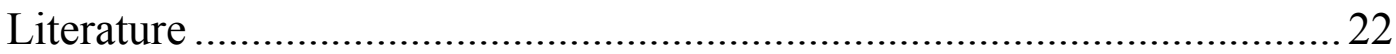




\section{LIST OF TABLES}

Table 1. The fees for withdrawal of 1 ha of land from agricultural production (tons) .....8

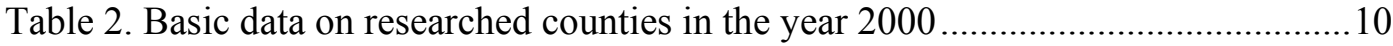

Table 3. Technical infrastructure of selected counties in 2001 ....................................13

\section{LIST OF FIGURES}

Figure 1. Bodies participating in master plan preparation. .......................................

Figure 2. Location of investigated counties ........................................................... 10

Figure 3. County budget revenue from personal income taxes...................................... 11

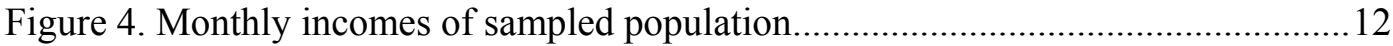

Figure 5. Agricultural land over the period of 1993-2000 ............................................ 14

Figure 6. Total and own budget revenue of Piaseczno County over the period 19942000

Figure 7. Total and own budget revenue of Stawiguda County over the period 19942000

Figure 8. Scope of threats resulting from settlement of urban people according to rural

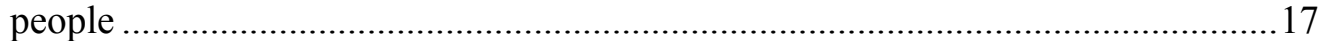

Figure 9. Factors driving farmers to land sales for non-agricultural purposes ................18 Figure 10. Factors supporting approval for land conversion by non-farm rural people .19 Figure 11. Enterprises conducting economic activity in Stawiguda County and nearby province capital, Olsztyn.................................................................................20

Figure 12. Enterprises conducting economic activity in Piaseczno County and nearby province capital, Warsaw

\section{Abbreviations}

CSO: Central Statistical Office

GLP: Green Lungs of Poland

OJ: Official Journal

ST: $\quad$ State Treasury 


\section{INTRODUCTION}

Rural landscape has decreased over the past ten years not only in Poland but all over Central and Eastern Europe (Ryszkowski, 1994). This process has especially concerned those areas neighbouring urban agglomerations. In many cases, local and state decisionmakers consider urbanisation to be a chance for local economic development. However, the continuation of that process requires more and more land, including areas which are environmentally valuable, to be converted into housing sites (Misiak, 1994). In this respect, the problem of land conversion has become one of the most current and urgent in Central and Eastern European Countries (CEECs), and has triggered the necessity of green space preservation.

The land conversion issue has appeared at a time when CEE governments have extended private control over land and shifted decision-making powers from the central to local level. Since then, farmers have been able to decide on land sale or purchase independently (Swinnen, Buckwell, Mathijs, 1997). Most restrictions and difficulties related to land turnover were lifted, e.g., a supplementary tax for people growing rich in Poland. Moreover, local government administration was replaced with self-government (Cichocki, 1996). The aim of the new local authority in Poland is to satisfy the common needs of broad local society, to create the background for rational and harmonised development of managed territorial units, and to provide a basis for balanced budgets.

In this paper, I argue that decentralisation and extension of private control over land has led to the loss of rural landscapes in Poland, because farmers, county self-governments and the broad rural society all gain from the conversion of agricultural land to housing land.

In the case of farmers, the low profitability of agricultural production, and the high prices of housing land cause their interest in land sale for non-agricultural purposes. Next, land conversion is considered by self-governments as a factor of economic development. Because of land conversion, county self-governments gain increased budget revenue and other benefits through the improvement of physical infrastructure. The third group of actors, i.e., the broad local society, also expect benefits such as new employment opportunities and the provision of some services for newcomers.

My argument is formed by literature on environmental changes, decentralisation and privatisation, and agriculture restructuring in CEECs. Simultaneously, literature regarding urban society, as well as urban and regional dynamics, was exploited for this paper. The main thesis of this article is also based on property rights theory and property rights regimes.

The paper reports findings from research in two counties in the environs of Warsaw (Piaseczno county) and Olsztyn (Stawiguda county), two major urban centres in Poland. The first county is located in the Mazowieckie province, which is the largest in Poland with respect to total area, the number of inhabitants and the acreage of agricultural land. At the same time, some rural areas had a direct influence on the most dynamic centre in Poland, the capital city Warsaw.

The second researched county is situated in the province of Warminsko-mazurskie, which occupies a high position with regard to natural resources. This region belongs to 
the so-called "Green Lungs of Poland," and contains high levels of bio-diversity and specific landscape features. Data and information were collected through the examination of archival records, documentation review and semi-structured interviews. Within the framework of field research, 38 interviews were conducted; they concerned county offices, urban dwellers, farmers and families who don't own land. The review of documentation concerned legal acts of the Republic of Poland, the decisions and regulations concerned County Councils and articles in local press.

The paper proceeds as follows. Firstly, the national policy towards land conversion and local settings in the aspect of the above process are analysed. Secondly, the scope of land conversion and the processes affecting it, the decentralisation and extension of private control over land, are examined at the local level. Thirdly, the politics of land conversion in both counties are investigated. In addition, this section focuses on the similarities that farmers, self-governments and broad local society all have in their approach to urbanisation. Finally, the differences in land conversion between investigated counties, resulting from urban demand on housing land and employment opportunities, are analysed.

\section{BACKGROUND}

\subsection{NATIONAL POLICY}

\section{Decentralisation}

Decentralisation in Poland is a process of relegating tasks to the units operating at a lower administrative level, with freedom as regards their elaboration. The Constitution of the Republic of Poland defines decentralisation of public governance (Art. 15), pointing out that the enforcement of the rule shall be done in the form of self-governments. The process of decentralisation in Poland started in 1989 with the establishment of basic level of county self-governments.

According to Article 6 of the Act on Local Self-governments, ${ }^{1}$ all local public matters are under the authority of county self-governments. The aim of a county shall be to match the common needs of local community, the creation of background for the rational and harmonised development of a county, and the conditions for full participation in the county in the lives of its inhabitants."

The main objective of a county (gmina) is the assurance of the common needs of a selfgoverning community. Some detailed internal tasks of a county are (1) the assurance of spatial order as regards land economy and environment protection, and (2) maintenance and operation of technical infrastructure within county boundaries.

In comparison to the period prior to 1990 , counties gained much more competencies as regards the management of land. Before that time, a county as an administrative level of central government had restricted authorisations in this respect. It only realised state policies. The majority of decisions were up to the president of a province.

\footnotetext{
${ }^{1}$ O.J. No 16 , pos. 95 of 1990 
The second stage of decentralisation in Poland started in 1998. On the basis of the Act of 24.07.1998, a three-stage territorial division of the country was implemented. The counties, districts (poviat) and provinces (voivodship) have become basic territorial units since 1.01.1999. Districts are the new administrative units that were established by this reform. The necessity of district establishing appeared because the number of provinces was decreased from 49 to 16 . Now, all public tasks of inter-county character are the main duties of a district or province.

\section{Extension of private land rights}

A term "land property" according to Polish legislation means the land with all included items of the property, excluding buildings and houses if they are considered as a different subject of property rights. In case of physical and legal persons, prevailing regulations do not impose any restrictions on the disposal of properties (land) to third parties. The contract of sale/purchase in this case shall be concluded in the form of a notarised deed. Legislation assumes only the possibility of expropriation of the owners of immobility for public purposes. The expropriation of the owners of immobility or other rights is done by compensating an owner with a sum equal to the expropriated property, or the relevant property right paid an expropriated owner.

Before the reform in 1989, there existed some restriction in Polish legislation related to land turnover. The upper limit of farm size could not exceed 50 ha. in Central and Eastern Poland and 100 ha. in Northern and Western Poland. Moreover, the taxation system was very repressive regarding land sale or purchase. The legislation gave some possibilities to impose supplementary taxes for so-called nouveau riches; this has led to the situation of informal land turnover. Similar circumstances concern land inheritance matters. Considering the above-mentioned issues, a lot of Polish farmers still don't have physical property rights to used land.

\section{Decentralisation and land conversion}

Only areas that are marked in land registers as wastelands, and in the case there exists a lack of these, other lands that have been assigned the lowest quality rating, can be designed for non-agricultural use. In case of construction and development or modernisation of buildings, such solutions have to be used so as to restrict negative impact on

Figure 1. Bodies participating in master plan preparation.

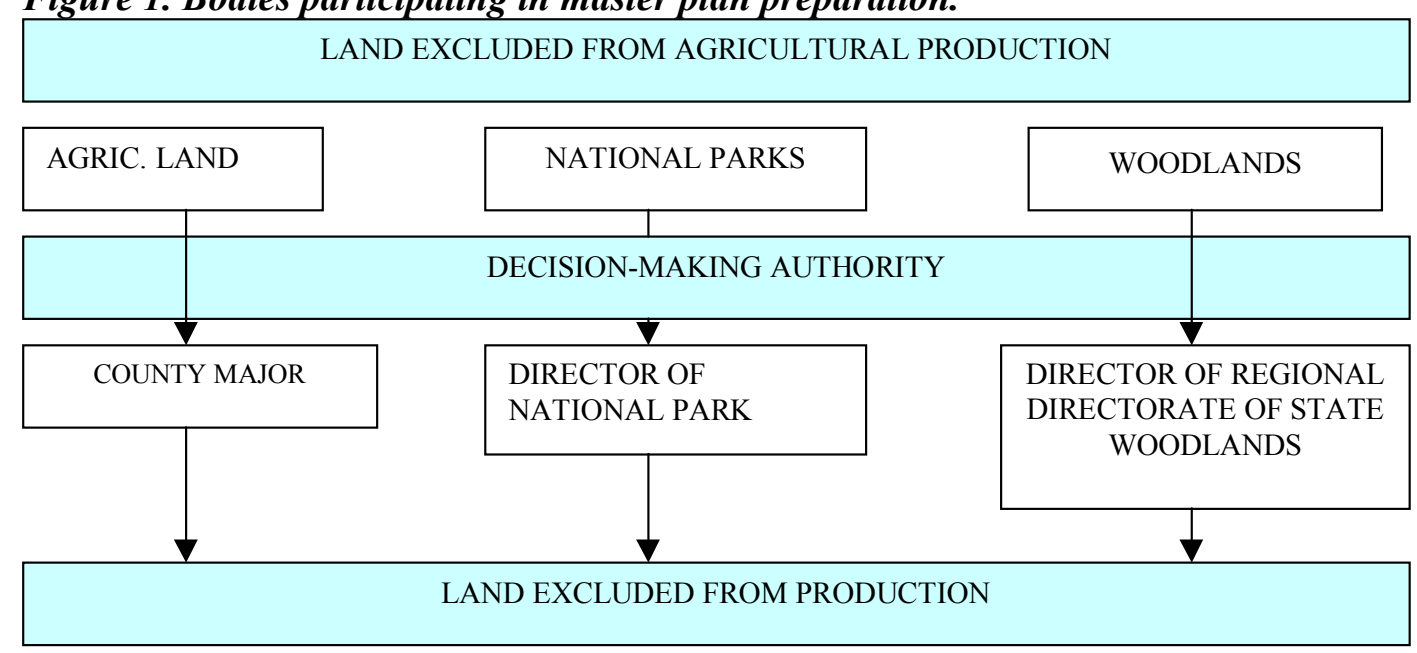

Sustainable Agriculture in Central and Eastern European Countries (CEESA) 
land. Local plans for spatial development are a basic measure for the disposal of agricultural land plots for non-statutory purposes. It is necessary to add that the preparation of this plan is a key task of county self-government, but with respect to protected areas such as national parks, reserves or landscape parks, it has to be negotiated with the responsible administration (Figure 1). The management situation in Protected landscape areas is a little different; these areas do not have a separate body to administrate them and their main function is to be corridors between the above-mentioned protected areas. However, they are under county self-government administration, and the county has to respect the restrictions related to this form of environmental protection.

The act of 7.07.1994 on Spatial Development (O.J. No 89, pos. 45) is the legal basis for the approval of plans for local spatial development. The Act defines the range and the principles of proceedings of land disposal for certain purposes, and the rules of their development. The principle of sustainable development is a basic consideration in this respect. According to the Act, every individual or entity has the right to develop a plot to which it is legally entitled within the limitations defined hereby and within the rules of community life. In case of the disposal of consolidated arable land with the area exceeding 0.5 ha included to I, II and III quality grades for non-agricultural purposes, it is necessary to obtain the permission of the Minister of Agriculture and Rural Development. In case of the disposal of agricultural land of IV quality grade with area exceeding 1 ha, and certain agricultural lands of V and VI quality grades, the President of the relevant province issues the permission.

The above permissions are issued following a proposal from the relevant county. The county board can approve a decision on the protection of agricultural land of lower quality grades. A person who obtains the permission for withdrawal of agricultural land

Table 1. The fees for withdrawal of 1 ha of land from agricultural production

\begin{tabular}{|c|c|c|c|}
\hline \multicolumn{2}{|c|}{ Arable land and orchards } & \multicolumn{2}{|c|}{ Pasture and meadows (P\&M) } \\
\hline Grade & Equivalent tons of rye & Grade & Equivalent tons of rye \\
\hline \multicolumn{4}{|c|}{ Land evolved from soils of mineral origin } \\
\hline I & 750 & $(\mathrm{P} \& \mathrm{M}) \mathrm{I}$ & 750 \\
\hline II & 650 & (P\&M) II & 620 \\
\hline IIIa & 550 & (P\&M) III & 500 \\
\hline \multicolumn{4}{|c|}{ Land evolved from soils of organic origin } \\
\hline IVa & 350 & (P\&M) IV & 300 \\
\hline $\mathrm{IVb}$ & 250 & (M) V & 250 \\
\hline $\mathrm{V}$ & 200 & (P) $\mathrm{V}$ & 200 \\
\hline VI & 150 & (P\&M) VI & 150 \\
\hline
\end{tabular}


from production is obliged to pay a single fee, as well as annual fees for permanent exclusion of the land from agricultural production. The value of the single payment (Table 1) is expressed as a value of fixed tonnage of rye according to the prices announced by Central Statistical Office (CSO). Such fees can be suspended if withdrawal of the land from agricultural production concerns the creation of housing sites up to 0,05 ha under a single-flat house, and up to 0,02 ha under for every flat in a block of flats. These regulations allow for locations of farm habitat buildings in rural areas if the criteria specified in a local development plan are fulfilled. The criteria are defined and issued by the mayor of a group of villages (mayor of a town/county, president) once the decisions and concerns required by the Act, and other specific regulations are obtained.

\subsection{LOCAL SETTINGS}

\section{Specific features of investigated counties}

The process of conversion of the land from agricultural use to suburban housing sites is undergone at the county level - a basic administrative unit. A county self-government has a wide range of entitlements in this respect. Certain factors such as geographic location, human resources and income level of the inhabitants set the decision-making process regarding land conversion. These factors shape the attitudes of local selfgovernments, farmers, families with no land, and rural people, towards agricultural land exclusion. The analysis of changes and spatial differentiation of the above factors is of particular importance in the concerned counties as well.

The counties are located in regions which, from a socio-economical standpoint, have developed very differently during transformation. On the other hand, their location is in the neighbourhood of their respective province capitals, and large acreage of preserved areas (especially preserved landscape) is common in both of the counties (Figure 2, Table 2). Almost all of the area of Stawiguda County, and about $75 \%$ in Piaseczno County is subject to legal protection. Agricultural land in Stawiguda County constitutes almost $25 \%$ of total area. The area of agricultural land and its share in total area in Piaseczno County are significantly higher.

As it comes from the relations between total area and the area of agricultural land, and the area preserved, both of the Counties have some part of their agricultural land subject to legal protection. The law protects all agricultural land in Stawiguda County. Both of the Counties also contain areas that are valuable for environmental reasons, and which could be used for housing sites due to their location near large cities. The County of Piaseczno is much more exposed to landscape degradation because it remains under the direct influence of the rapidly growing agglomeration of Warsaw. The influence of only the province capital - Olsztyn on Stawiguda County and lower economic growth rate of Warminsko-mazurskie Province cause significantly lower scope of land conversion than it is in the Province of Mazowieckie. The larger size of environmentally valuable areas (in relative terms) in Warminsko-mazurskie Province may mean that even low levels of land conversion could have noticeable outcomes, such as the reduction of bio-diversity and changes in landscape.

The population density of the Counties requires our attention in this respect. There are 26 villages in Piaseczno County per $100 \mathrm{~km}^{2}$; this density amounts to 345 people per $100 \mathrm{~km}^{2}$, while relevant figures for Stawiguda County are 8 villages and 21 people per

Sustainable Agriculture in Central and Eastern European Countries (CEESA) 
$100 \mathrm{~km}^{2}$, respectively. Such diversity is also a characteristic feature of the provinces where the Counties are located.

\section{Figure 2. Location of investigated counties}

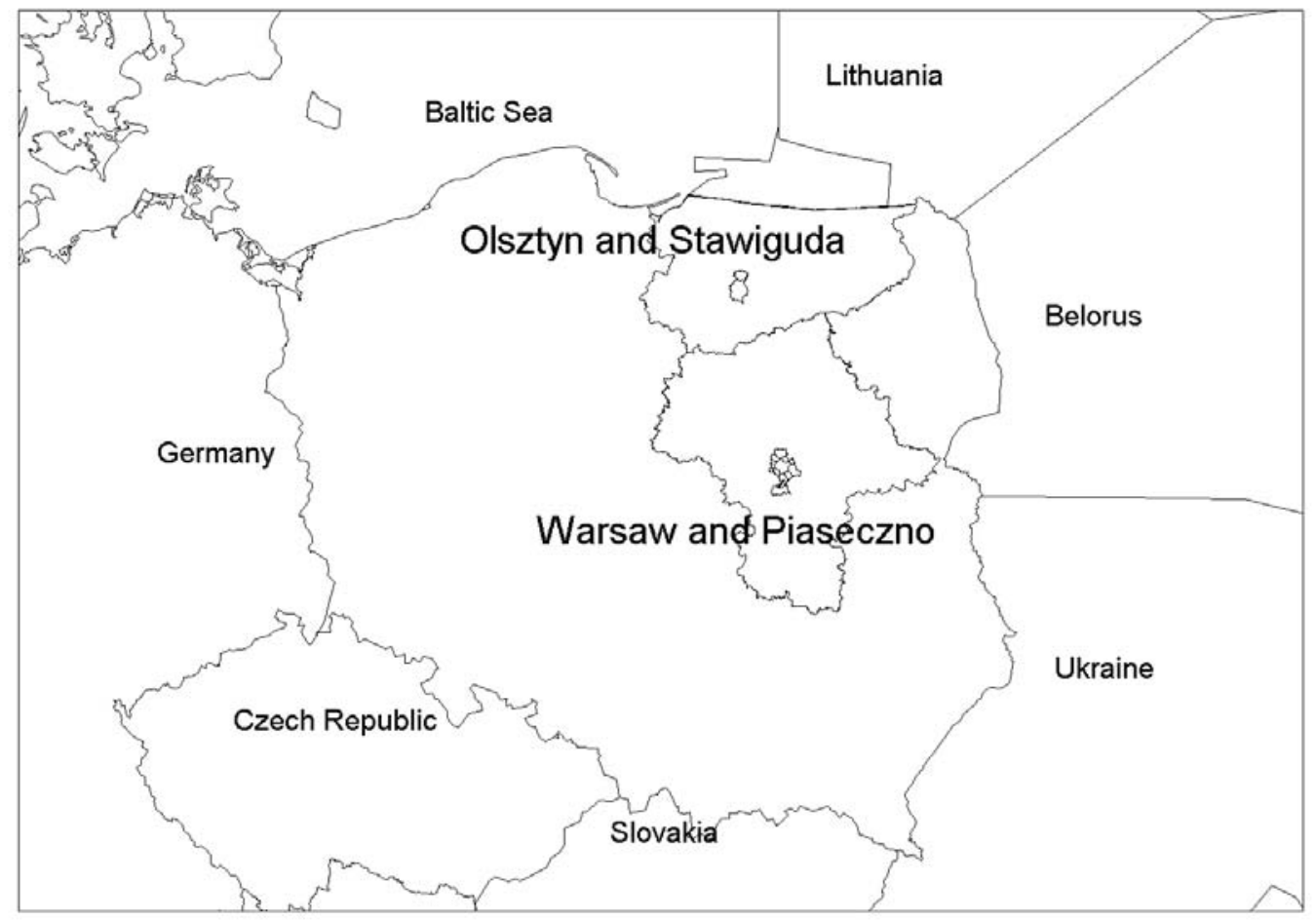

Table 2. Basic data on researched counties in the year 2000

\begin{tabular}{l|ll}
\hline County & Stawiguda & Piaseczno \\
\hline Province & Warminsko-mazurskie & Mazowieckie \\
Population & 4728 & 44204 \\
Total area (ha) & 22254 & 12822 \\
Agricultural land area (ha) & 4989 & 6688 \\
Number of villages & 18 & 34 \\
Preserved area (ha) & 22250 & 9303 \\
\hline
\end{tabular}

Source: Central Statistical Office (CSO). 


\section{Incomes}

People's incomes are an important factor which affect attitudes towards land conversion. The level of incomes can lead to an approval or refusal of land conversion. In order to investigate this issue in selected counties, the level of budget revenue generated by personal income tax was used (Figure 3). Public statistic services in Poland do not collect data on personal incomes. In fact, budget revenue of personal income tax is a function of real incomes gained by the population because self-governments at present receive $27.6 \%$ of this tax. Elaborated analysis shows that the population of Piaseczno County earn higher incomes than the population of Stawiguda County. Additionally, up to the year1996 we can observe constant differences between people's incomes in selected counties. After that the difference has widened. For the time being the incomes of the people in Piaseczno County are twice as much as those in Stawiguda County.

\section{Figure 3. County budget revenue from personal income taxes}

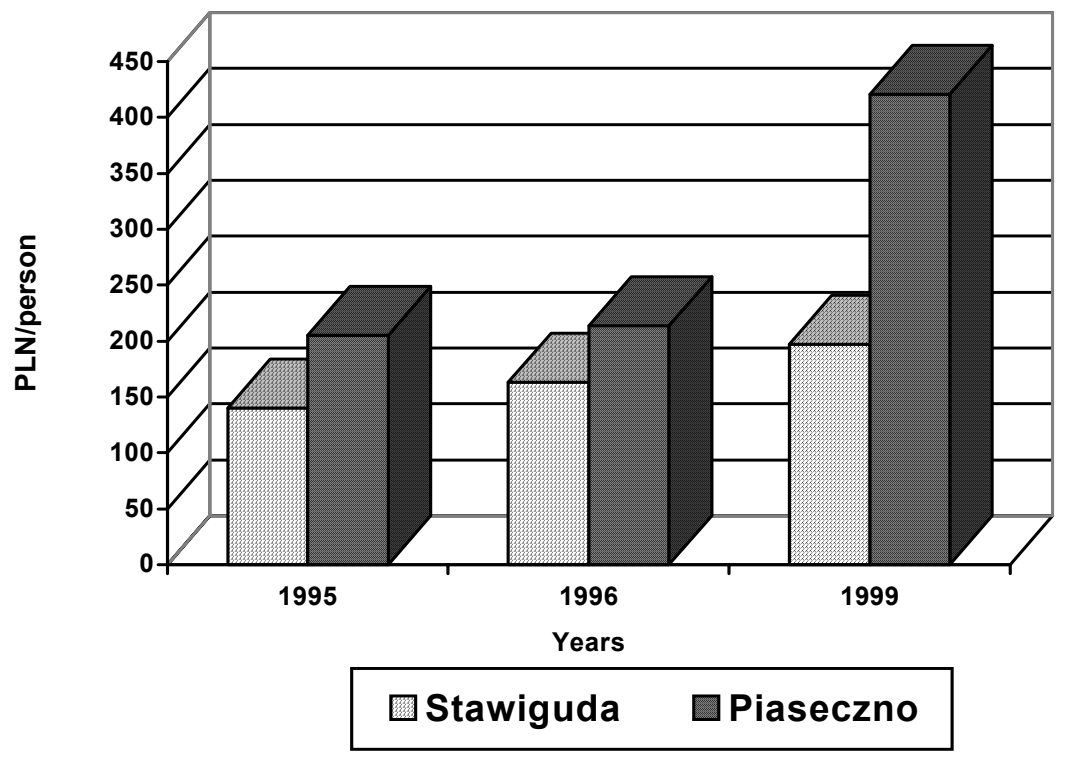

Source: Central Statistical Office (CSO).

The incomes of examined groups (Figure 4) of people in the concerned counties were different as well. Farmers in Stawiguda County earned significantly higher incomes than farmers in Piaseczno County. But the farmers in Stawiguda County often operate on farms with 50-1000 ha and more. On the opposite pole, the farmers in Piaseczno County mostly own just several-hectare farms. Moreover, family members who were farm owners in Piaseczno County gained incomes from non-agricultural sources (jobs) as well. Such situations did not exist in Stawiguda County, where farmers and their families dealt exclusively with on-farm work. Agricultural incomes in Poland are not taxed, therefore the above-described revenues on income tax do not represent the incomes of this group of rural people. 


\section{Figure 4. Monthly incomes of sampled population}

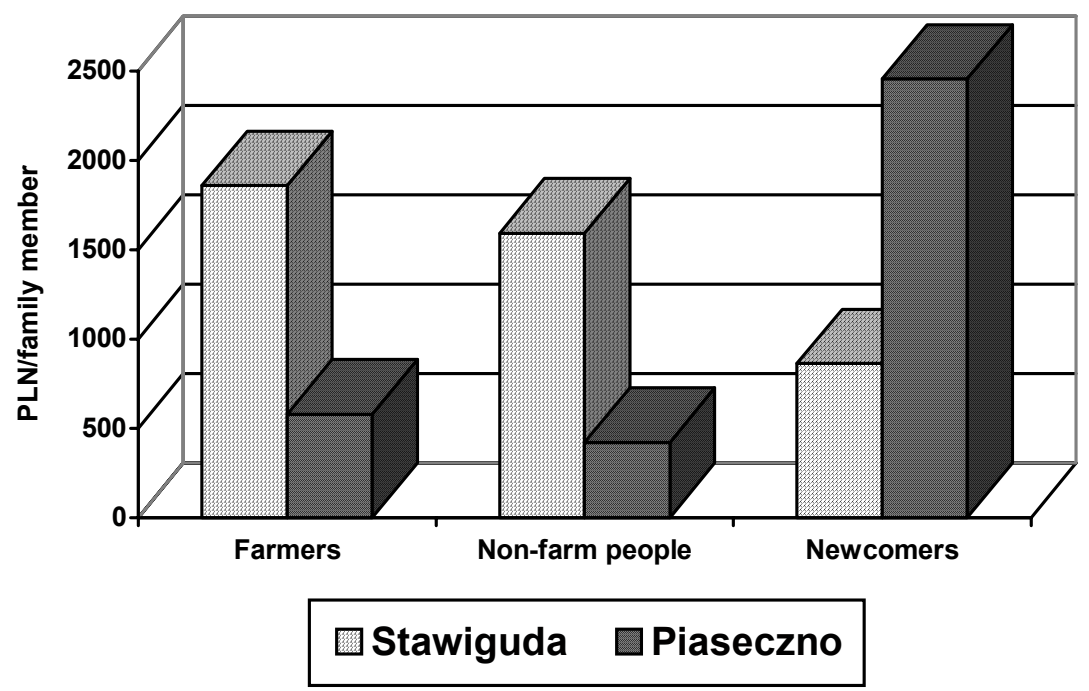

Source: questionnaire.

The incomes of rural people not involved in agriculture in the concerned counties were similar (Figure 3). However, they result from the fact that those people in Stawiguda County were often involved in the private sector or were running small enterprises; in Piaseczno County they worked mostly as contractors. It has to be stressed that there is also a large group of contractors in Stawiguda County, but which receive much lower incomes than their counterparts in Piaseczno County.

The incomes of urban newcomers in various selected counties were quite different. Newcomers in Piaseczno County received incomes that were twice as much as those in Stawiguda County. Moreover, their income level was higher than the income level of all other groups of inhabitants. On the other hand, in Stawiguda County, urban people earned the lowest incomes among those interviewed.

The high income level of newcomers in Piaseczno county is the result of workers from the Warsaw agglomeration. This city is characterised by the highest level of salaries in all sectors of Polish economy. It also has the lowest unemployment rate. These factors, plus the high prices of land and flats in Warsaw cause the migration to the nearest suburban counties, e.g., Piaseczno.

People with higher incomes in most cases tend to match the needs of a higher standard, including environment protection, bio-diversity and landscape preservation. However, the research results show that in order to evolve to such a stage, a certain minimum level of income has to be earned by a great majority of society. None of the selected 
counties have yet reached this stage of development. The development of suburban housing sites, and so the withdrawal of the land from agricultural production, are widely accepted. Farmers and other rural people share such attitudes. The owners of large farms and individuals running their own profitable businesses are not interested in the intensification of this process.

\section{Infrastructure}

Well-developed elements of technical infrastructure significantly lower the investment costs of the new settlers linked to the construction of houses, and in the long run lead to the decline of maintenance costs. Urban people are also very much concerned about the social infrastructure of an area, for example, reasonable location of schools, libraries, health centres, or cinemas. Conducted field research allows us to say that the majority of counties' existing technical infrastructure was built before 1989, i.e. prior to transition. During the last decade there were some investments in modernisation of water supply networks, sewage systems and the system of waste removal. While assessing the differences between selected counties, it has to be underlined that the County of Piaseczno has significantly better developed physical infrastructure (Table 3). The weakest element in both of the counties is their sewage systems, which is a characteristic feature of rural areas in Poland. High population density and the pattern of settlement networks make Piaseczno County involved in the investments linked to enlargement of the sewage system; however, high costs of this system limit its scope. The situation in this respect in Stawiguda County is different. This county is characterised by serious shortages of all analysed elements of technical infrastructure. Piaseczno County is also more developed as regards particular elements of the social infrastructure. However, interviewed individuals living in urban areas pay less attention to social infrastructure than to technical infrastructure as attractive settlement factors. This results from a close location of the counties to the capitals of relevant provinces, i.e. Warsaw and Olsztyn. This reflects the fact that these counties' inhabitants have opportunities to use health centres, cinemas or libraries placed in those cities. More attention was only paid to the quality of equipment and the level of teaching in primary schools.

To recapitulate, it has to be said that the influence of social infrastructure on the level of land conversion is slightly lower that it is in case of technical infrastructure. Nevertheless, some elements of social infrastructure such as primary schools are necessary for this process.

Table 3. Technical infrastructure of selected counties in 2001

\begin{tabular}{|l|l|l|}
\hline Item: & Stawiguda & Piaseczno \\
\hline Share of villages with water supply system (\%) & 61 & 100 \\
\hline Share of villages with sewage system (\%) & 7 & 6 \\
\hline Share of villages connected to waste treatment stations (\%) & 61 & 100 \\
\hline Share of villages with transportation of wastes to dump grounds (\%) & 28 & 100 \\
\hline
\end{tabular}

Source: questionnaire. 


\section{LANd Conversion in Selected Counties}

The counties selected for the study are characterised by relatively high acreage of agricultural land valuable for environmental purposes, or located in areas with attractive landscape. As it comes from collected data since 1993, the area of agricultural land has been gradually declining (Figure 5). Between 1993-2000, the area of agricultural land shrunk by 622 ha in Stawiguda County (11.1\% of the county agricultural land), and by 671 ha in Piaseczno County (9.2\% of the county agricultural land). The process has undergone a similar pattern in the two counties. The largest area of agricultural land in Piaseczno County was converted in 1997. A similar phenomenon was observed in Stawiguda County. However, it took place gradually, concerning two consecutive years.

Figure 5. Agricultural land over the period of 1993-2000

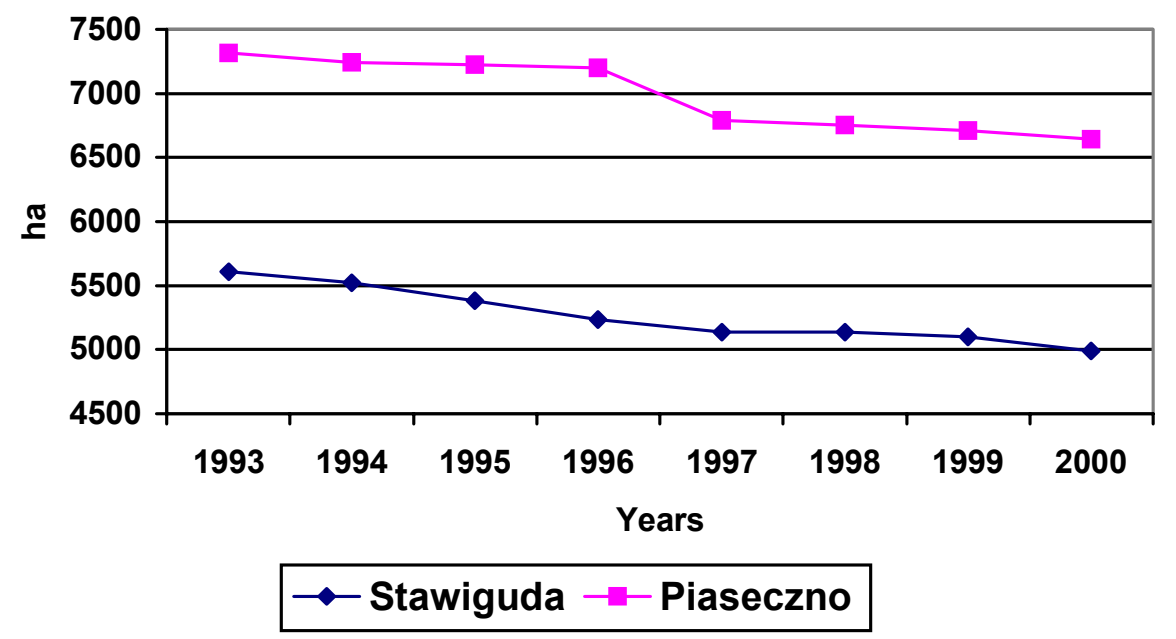

Source: questionnaire.

Land excluded from agricultural production is not entirely utilised for housing sites. Certain parts of this land are afforested, used for mining or for the development of infrastructure (e.g. roads). However, land allocation is closely related to the plan of spatial development of a county. The phenomenon of declining agricultural area does not explain the real scope of housing development. The real size of land allocated for housing sites is set in the plan of spatial development. From 1994-2000 in Stawiguda County, 32.5 ha of agricultural land was allocated for housing (excluding the area allocated previously). At the same time, 86.5 ha or $13.9 \%$ of excluded agricultural land was converted. In fact, we did not collect relevant data for Piaseczno County, but 1,920 ha of agricultural land is fixed for conversion into housing sites in the county plan of spatial development for the years of 1994-2000. Such a figure proves the high speed of the conversion process and the ever-growing demand for land. Additionally, the County Council approved a regulation concerning the procedure of conversion for the next 900 ha. So the scope of the process in Piaseczno County is enormous. Once all the agricultural land allocated for housing sites, and the land for which the conversion procedure has just started, are used for housing, the county will have lost about $50 \%$ of its agricul- 
tural land. Such a situation may minimise the role of the people involved in agriculture, and may also cause a significant and unrecoverable reduction of rural landscape, including landscape differentiation. This is a very important issue connected with environmental protection as well. Most areas of these counties (the whole area in Stawiguda County) are protected by Polish law. The standard form of environmental protection, so-called "protected landscape area", meets the following demands:

- The protected landscape area shall embrace sites of distinctly diversified landscape occupied by various ecosystems. The management of those systems shall ensure the status of a relative ecological balance of the natural systems.

- The protected landscape areas shall be taken into account in the land use management plans.

\section{Politics OF LAND CONVERSION}

\subsection{COUNTY SELF-GOVERNMENTS}

\section{Budget}

County self-governments gain increased budget revenue from land conversion. Firstly, it results from the change in the tax system; i.e., the revenue on agricultural tax is replaced with the revenue gained on real estate tax. In addition, the inflow of urban people gives rise to the revenue generated by tax on personal incomes. All of these taxes are the major components of revenues. The importance of the increase of incomes in this respect largely results from the level of incomes generated in studied counties (Figure 6, Figure 7). The process of land conversion leads to significant increases of revenue in both of the counties. However, the revenue generated this way in Piaseczno County is 10 times higher than in Stawiguda County. Such a difference explains why Stawiguda County is more interested in all possibilities of rising incomes. The scope of land conversion in Piaseczno County - resulting from greater interest of urbanites - creates a different way of explaining the change in land use. The official explanation of decisions resulting from direct financial budget gains could expose counties to critics from environmental organisations. On the other hand, the pressure from local society is also a basis for decisions on land conversion, and gives strong arguments for self-governments in case of potential conflicts. In case the counties are not reachable as such, including Stawiguda County, the utilisation of natural resources is often motivated by the necessity of obtaining funds to match the basic needs of local society, including social objectives such as the education of young people.

So land conversion for local self-governments is clearly a good way to improve their financial condition. This has been confirmed by analysing budget revenues from agricultural tax and real estate tax from 1994-2000. The budget revenue from agricultural tax in Stawiguda County fluctuated within a very low level (from 50000 to 150000 PLN). Thus, budget revenue in this tax category increased 3 times in nominal terms over the concerned period. In the case of the budget revenue form real estate tax, a $600 \%$ increase was observed. Therefore, a tendency for shares of agricultural tax in county incomes to decline in favour of increases in share generated by real estate tax has been observed, particularly in the last two years of the concerned period. Similar tendencies have been observed in Piaseczno County. However, this county generates significantly higher revenue from real estate tax than does Stawiguda County. 
Figure 6. Total and own budget revenue of Piaseczno County from 1994-2000

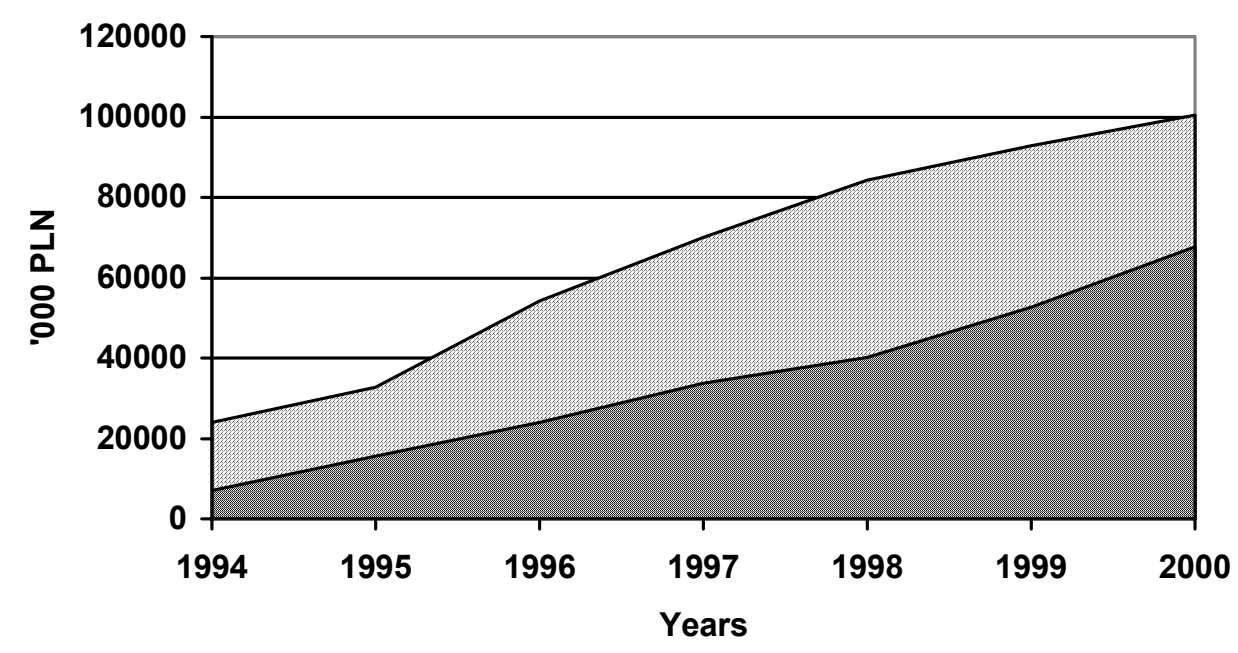

$\square$ Total revenue $\square$ Own revenue

Source: CSO.

Figure 7. Total and own budget revenue of Stawiguda County over the period 19942000

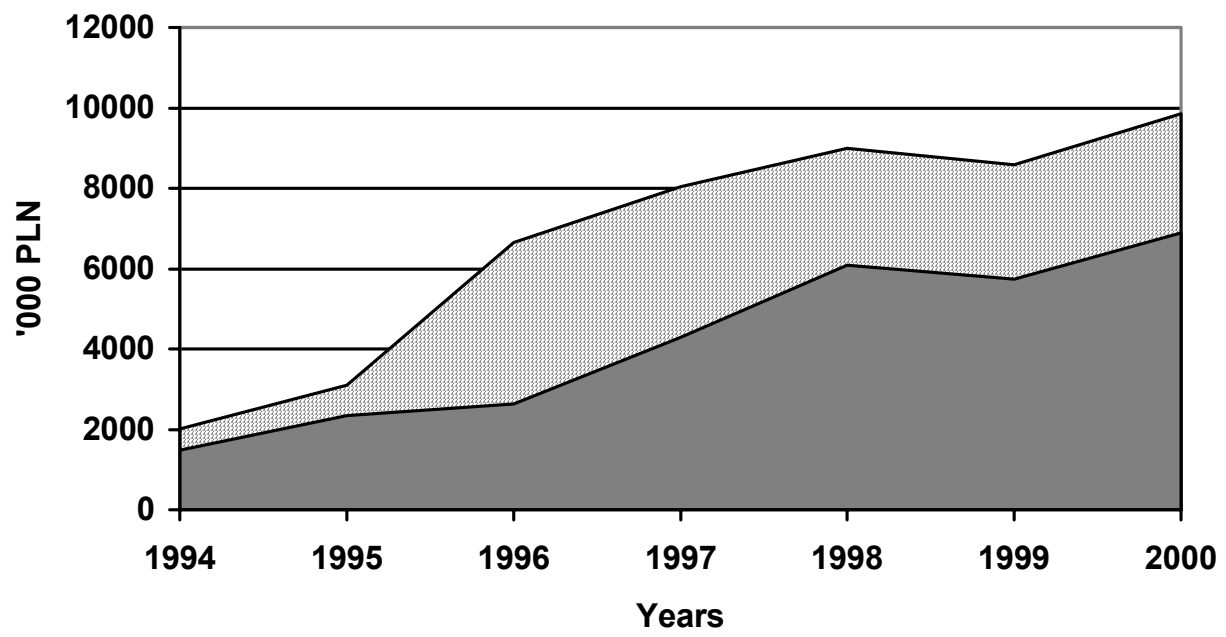

\section{Total revenue $\square$ Own revenue}

Source: CSO.

\section{Self-government authority as a decision-maker}

The County embodies a wide range of competencies regarding land conversion. Moreover, the urbanisation of rural areas is considered as a factor of local economic development, which in selected cases intensifies the process of withdrawal from land used for agricultural production. However, the present allocation of competencies in this respect, and the increasing scope of land conversion are positively assessed by local societies. 
None of the interviewed individuals had considered shifting these competencies from a county level to governing structures, a higher level of self-governments, or nongovernment organisations. On the other hand, the proportions of people happy with the present situation to those who have considered increasing the competencies of local self-governments are different. A great majority of interviewed individuals in Piaseczno County had considered increasing the competencies of self-government as regards land conversion, while in Stawiguda County most of the people were happy with the present situation. These divergent attitudes are caused by better organisation of the society of Piaseczno County, which can have a greater influence on the decisions of selfgovernment. There are social committees for the development of technical infrastructure. Conducted research shows that unorganised individuals do not have a strong influence of the decisions of self-government on land conversion. Sometimes, it also has a positive effect. An example is Piaseczno County, where there is pressure on farmers to convert the land. In many official's opinions, these farmers would like to convert almost the whole area of agricultural land.

\section{Priorities of local society}

Local societies do not consider land withdrawal from agricultural production as a factor causing the loss of rural landscape (Figure 8). Such attitudes support the approval of increased levels of land conversion planned by local self-governments. Some threats are

Figure 8. Scope of threats resulting from the settlement of urban people according to rural people

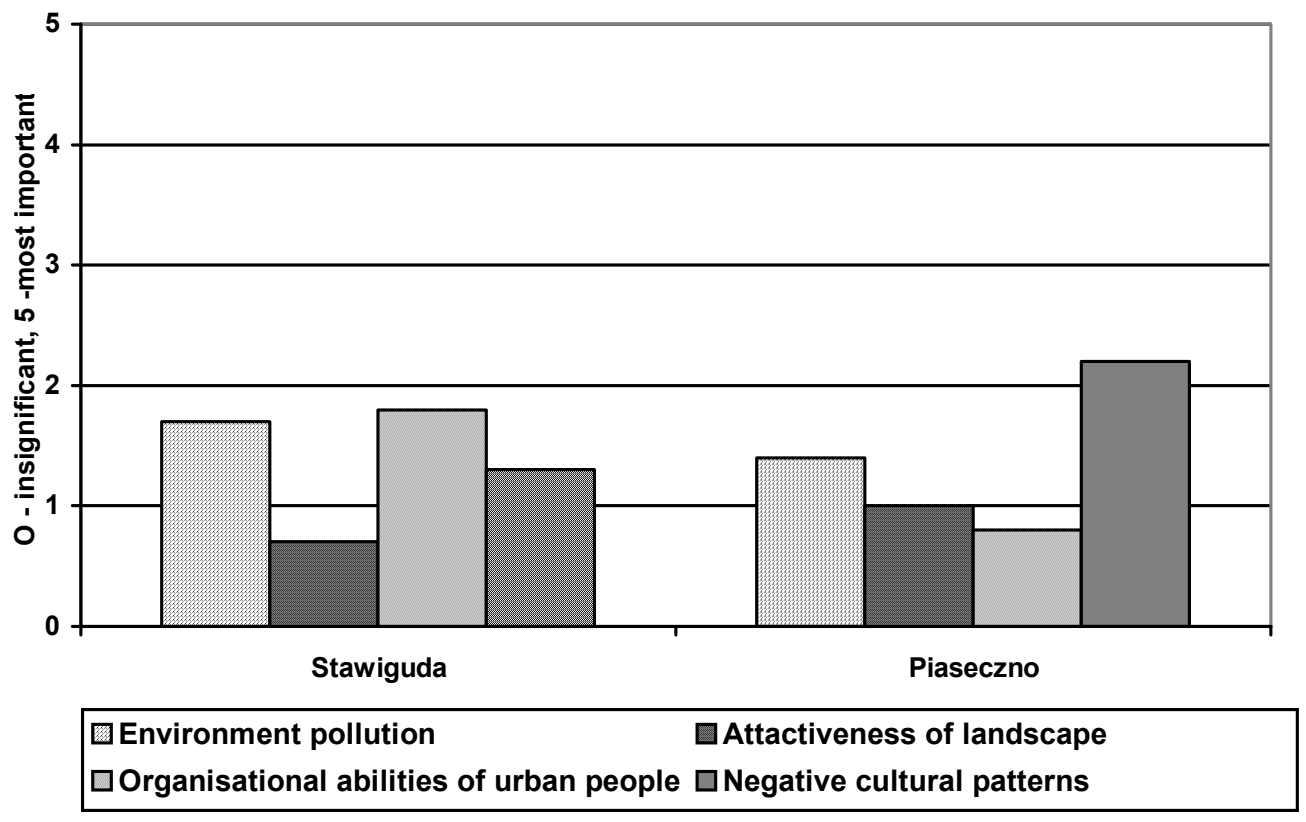

Source: CSO. 
perceived in the settlement of urban people but their extent is rather negligible. For instance, the increase of environmental pollution resulting from the inflow of people was assessed at 1.7 point in Piaseczno County and at 1.4 point in Stawiguda County on a 5point scale. The negative impact of the settlement on attractiveness and diversity of landscape was assessed even lower by rural people. The most serious threats of interviewed individuals were related to negative cultural patterns brought with the settlers and, concerned Piaseczno County.

\subsection{FARMERS}

This group is also considered an important player in the process of land conversion. Research tells us that farmers own almost the whole area of agricultural land that is used (and/or can be used) for housing purposes in the Counties of Stawiguda and Piaseczno. Therefore, the farmers decide whether or not the land is going to be converted. The majority of farmers expressed interest in the sale of land for non-agricultural uses (Figure 9). Such attitudes are more often found in Piaseczno County, which to a large extent results from the extremely fragmented farm structure in this region. The incomes generated from farms through agricultural activities do not assure the basic needs for the farmers' families. The conducted questionnaire shows the level of annual agricultural income per 1 ha amounts to about 2000 PLN per capita. On the other hand, the average price of 1 ha of agricultural land sold to urban people for housing amounts to 600000 PLN. The low profitability of agricultural production and the relation of agricultural incomes to the price of housing plots are the main factors supporting land sales by the

\section{Figure 9. Factors driving farmers to land sales for non-agricultural purposes}
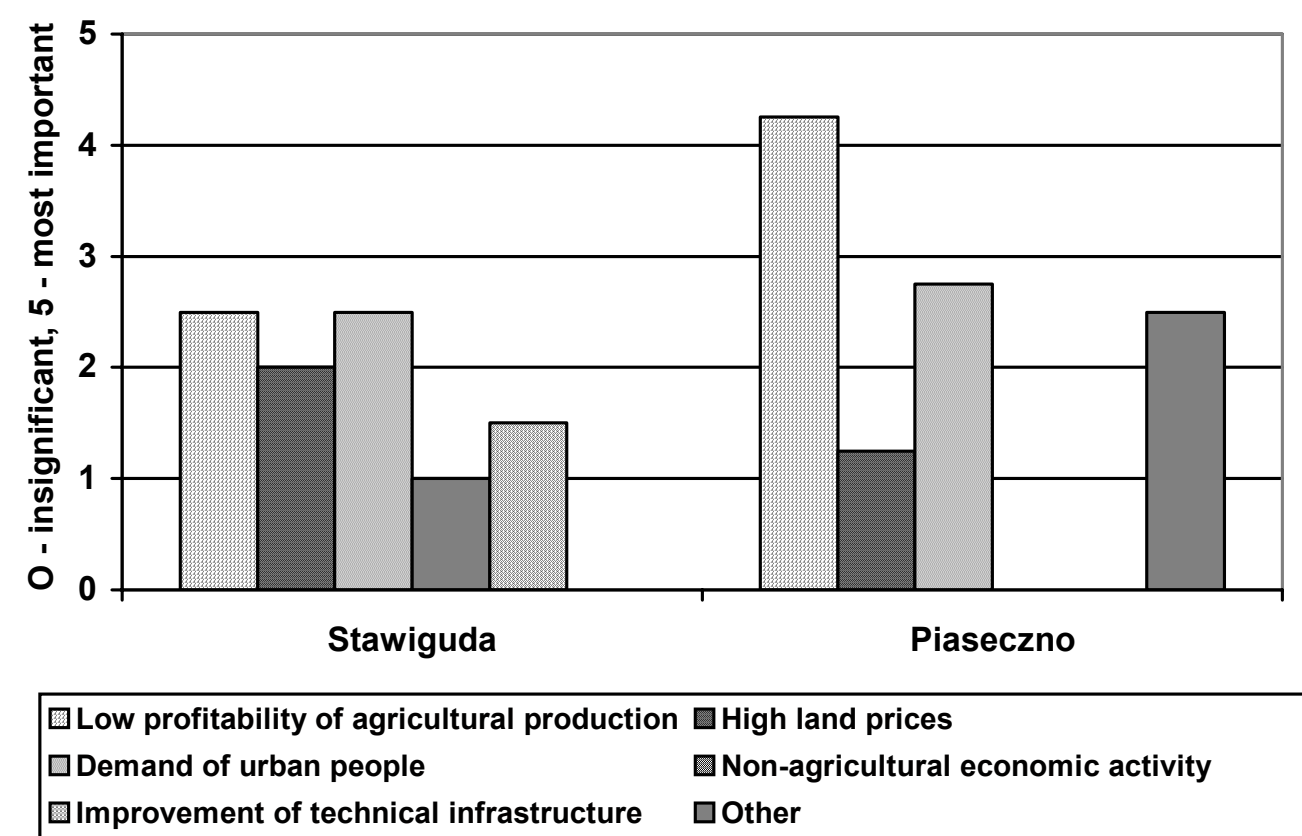

Source: CSO

farmers in Piaseczno County. Farmers in Stawiguda County consider the low profitability of agricultural production as a main factor of agricultural land sales as well. How- 
ever, lower land prices and higher levels of agricultural incomes in Stawiguda make this factor less important compared to Piaseczno County.

\subsection{NON-FARM RURAL PEOPLE}

The approval of the remaining part of rural society, i.e. the families without land ownership, is also an important element of land conversion for suburban housing (Figure 10). If they didn't approve of the process, its scope could be significantly limited. The low level of ecological awareness resulting from a lack of education of this group prior to, and at the beginning of transition, causes them to not consider land conversion as a threat to the environment. Moreover, a great majority of them reckon the process will bring clear gains for the county in the form of economic development, and will thus improve their living standards.

The interviewed individuals in both counties expect that the development of housing and the inflow of new people will result in the increase in the number of jobs and will create new demand for various services to be supplied by the locals. The possibility of infrastructure improvement is the next factor in this respect. The development of housing is often accompanied by the construction or modernisation of, for instance, sewage systems or the organisation of wastes collection and utilisation systems. On the other hand, the newcomers participate in the costs of such activities. The development of technical infrastructure is also perceived by rural people as a measure of environment protection, because it does not create any conflict of interests, and largely protects the environment from degradation.

Figure 10. Factors leading to approval for land conversion by non-farm rural people

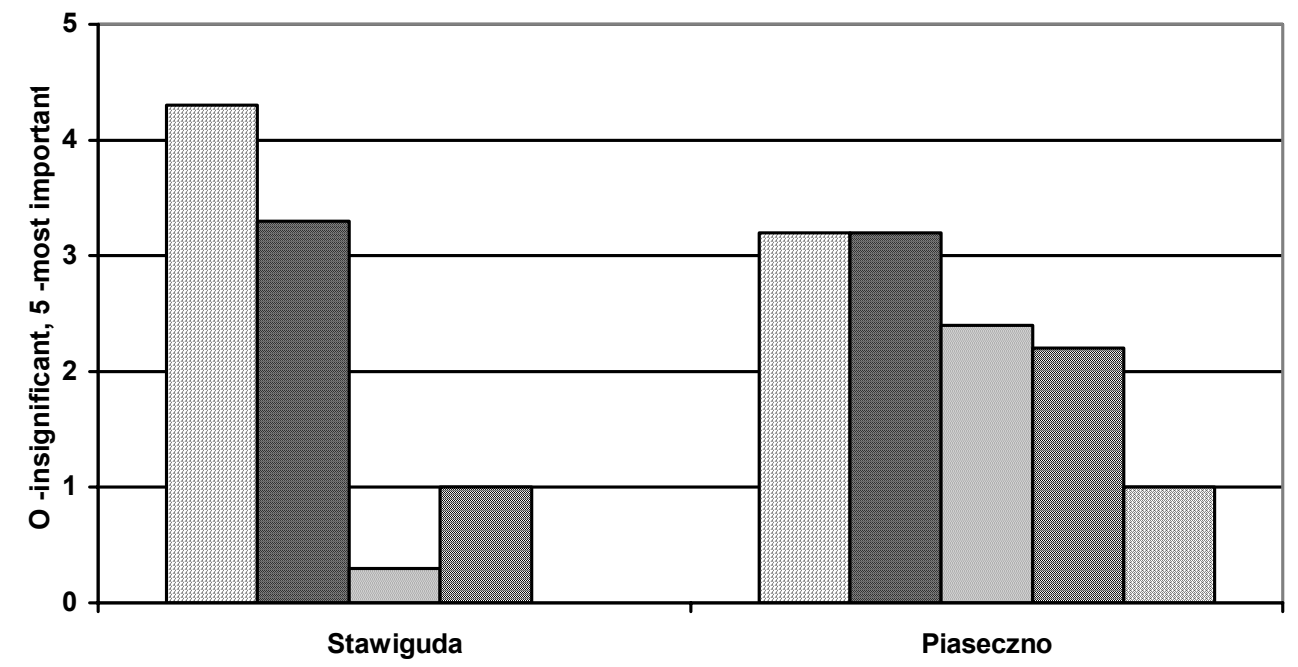

$\square$ Possibilities of additional employment $\quad \square$ Improvement of technical infrastructure
$\square$ Improvement of teaching level at schoools $\square$ Improvement of activities of local society
$\square$ Other

Source: CSO 


\section{DIFFERENCES IN LAND CONVERSION BETWEEN THE COUNTIES}

\subsection{URBAN DEMAND FOR HOUSING LAND}

The self-government activities aimed at the change of land use are a specific kind of response to demand for land shown by urban people. Such a demand is observed in both counties, with similar factors but differing intensity. Conducted research points to two major reasons for buying a housing plot in rural areas. In both counties it was an attractive environment, landscape and low land prices. In the case of land prices, the relation between housing sites in the selected counties to those in neighbouring province capitals is of particular importance. In most cases the land in these counties is several times cheaper than in the neighbouring cities. The close location to a city was pointed out as another important factor in Stawiguda County; this is linked to the cost considerations of travelling to a job in the city. According to earlier discussion, rural people settling in this county have significantly lower incomes than the people working in Warsaw and settling in Piaseczno County. Interviewed people in Piaseczno County considered low land prices to entirely compensate the increased costs of travelling to work.

\subsection{EMPLOYMENT OPPORTUNITIES}

The possibilities of employment in a county and a closely located province capital also affect the process of land conversion. In economic literature the ratio of the number of enterprises per 1,000 inhabitants at productive age (Figure 11, Figure 12) is used to assess the impact of employment possibilities on the process. Over the period of 19961999 the ratio in concerned counties clearly increased. In the Province of Warminskomazurskie, the province capital offers relatively greater possibilities of employment than the County of Stawiguda, while in the Province of Mazowieckie, Piaseczno County has the same possibilities of employment as the province capital Warsaw. It has to be underlined that the number of enterprises per 1,000 inhabitants in Piaseczno County and in Warsaw is significantly higher that in Stawiguda County and Olsztyn.

Figure 11. Enterprises conducting economic activity in Stawiguda County and nearby province capital Olsztyn

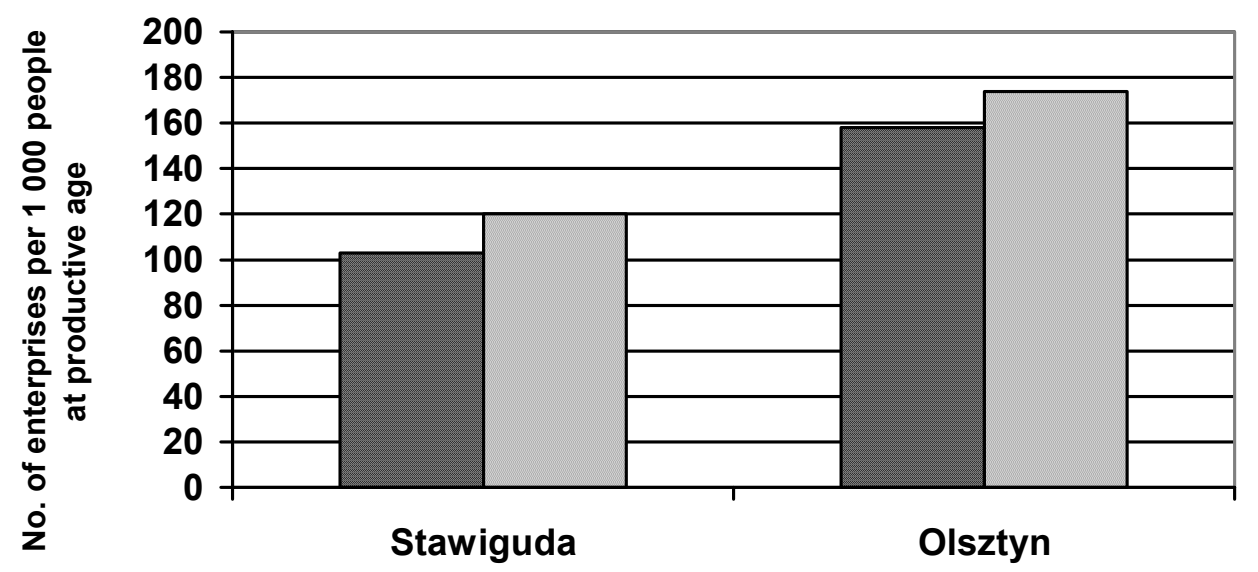

\section{$1996 \square 1999$}

Source: CSO 
The development of economic activities and related possibilities of employment explain to a large degree the scope of agricultural land exclusion for suburban housing sites in the concerned counties. Also, the increased rate in the number of enterprises is of crucial importance in this respect. In the concerned county of Mazowieckie Province, the increase rate reached 7\%, and doubled the rate recorded in the Province of Warminskomazurskie.

Figure 12. Enterprises conducting economic activity in Piaseczno County and nearby province capital Warsaw

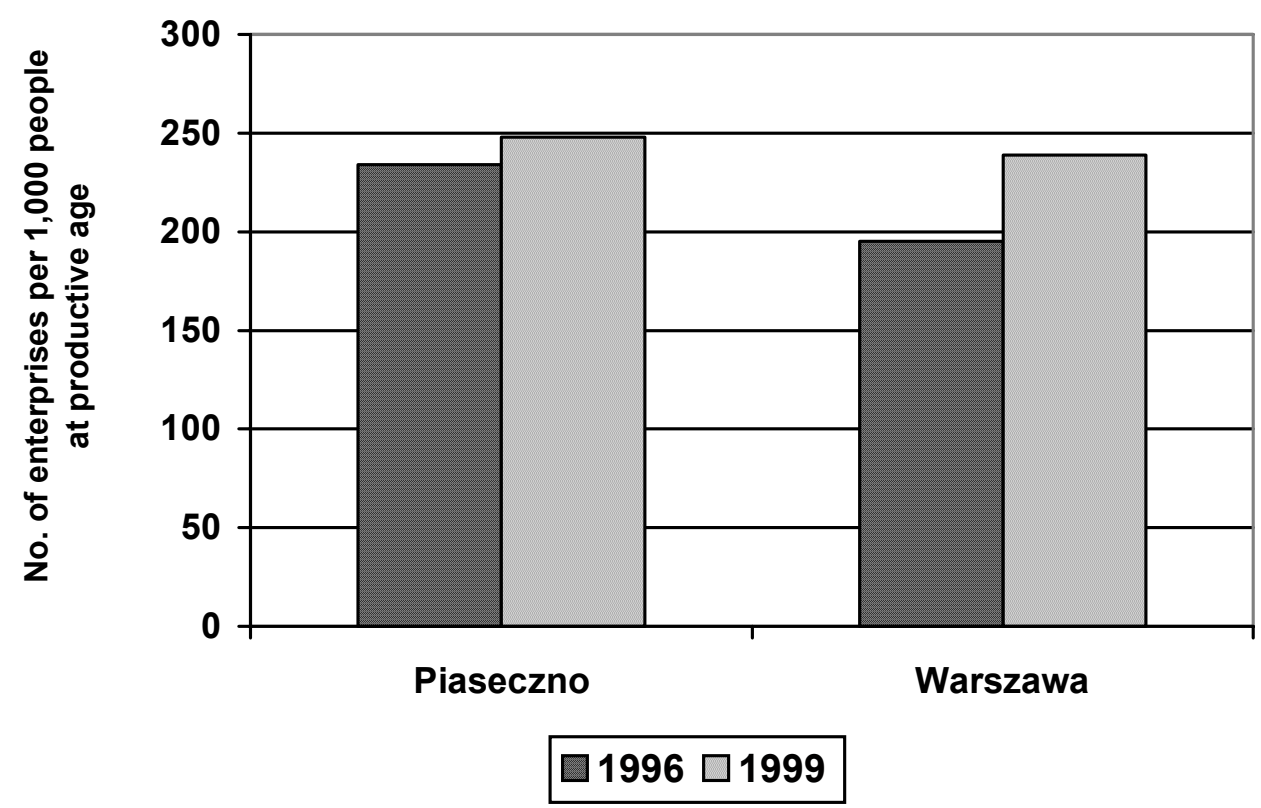

Source: CSO

\section{Conclusions}

The decentralisation of decision-making power towards local self-governments is of key importance regarding the process of land conversion. Formal approval of selected housing plots is up to local self-governments. In addition, county self-governments are obliged to support local development, which very often is considered to contribute to the economic and social development of a county. Accordingly, the environmental issues of development are often dropped. Conducted research to some extent confirms this thesis. The counties surrounding large agglomerations use land conversion as a factor of economic development and a way of improving the financial situation of county budgets. Therefore, such counties tend to match the demand for land created by urban dwellers. The thesis is additionally supported by the attitudes of rural people (who expect economic gains from housing development and the inflow of new inhabitants) towards the land conversion process. Simultaneously, neither rural people nor selfgovernments perceive the loss of rural landscape as a threat towards the environment. This situation can be explained from a social point of view because rural people generate relatively low incomes and accept almost every way of improving their standard of living. 
With respect to the above-mentioned findings, it is necessary to say that changes and the diversification of property rights and governance structures related to land management cause the reduction of rural landscape. There exist rules of land protection in Polish legislation, but we can also observe the lack of monitoring tools. In addition, the country is characterised by underdeveloped environmental groups, which could play a very important role in land management and landscape planning. In this respect, both the above mentioned factors and the knowledge of local society on environmental issues should be improved to ensure sustainable land use.

After 40 years of central planning, the decentralisation and extension of private control over land are necessary to involve local society in decision-making processes concerning their future. They should have an opportunity to choose the way their living area develops. The problem is that the knowledge, behaviours and attitudes of local society, moulded by their former economic system and current economic situation, affect their decisions. Such a situation sometimes leads to negative changes in the proportions between social, economic and environmental components of development. Especially when considering the natural environment, the execution of property rights and the activity of new governance structures should be under permanent control in order to prevent the irreparable changes as the loss of landscape.

\section{LITERATURE}

Anderson, T. L. and Hill, P. J. (eds.). 1996. The Privatisation Process: A Worldwide Perspective. Rowman and Littlefield.

Bromley, D. W. 1989. Economic Interests and Institutions. Oxford: Basil Blackwell.

Bromley, D. W. 2000. Environment and Economy. Oxford: Basil Blackwell.

Carter, F.W. and Turnock, D. 1996. Environmental Problems in Eastern Europe. London: Routledge.

Grafton, R. Q. 2000. "Governance of the Commons: A Role for the State." Land Economics 76 (4): 504-517.

Hagedorn, K. and Gatzweiler, F. 2001. The Evolution of Institutions in Transition. CEESA Discussion Paper no. 4/10/2001. Humboldt University Berlin.

Larson, A. M. 2002. "Natural Resources and Decentralization in Nicaragua: Are Local Governments Up to the Job?" World Development. Vol. 30, No. 1.

Misiak, J. 1994. A National Park at the City Gates: Kampinos National Park. Izabelin, Poland.

Ostrom, E. 1990. Governing the Commons. Cambridge: Cambridge University Press.

Plut, D. 2000. "Environmental challenges of Europe: The state of environment and enviromental trends in the EU (EU15) and the Accession Countries (AC10)." Geojournal 52: 149-155.

Ryszkowski, L. 1994. The Integrated Development of the Countryside in Central and Eastern European Countries. Polish Academy of Sciences. Poznan, Poland.

Schlager, E. and Ostrom, E. 1992. "Property-Rights Regimes and Natural Resources: A Conceptual Analysis." Land Economics 68 (3): 249-262. 
Swinnen, J. F. M., Buckwell, A. and Mathijs, E. (eds.). 1997. Agricultural Privatisation, Land Reform and Farm Restructuring in Central and Eastern Europe. Aldershot: Ashgate.

Wilczynski, P. 2000. "The Poland Rural Development Project." Third EU Accession Workshop in the Rural Sector. Sofia, Bulgaria.

World Bank. 1999. Legal Impediments to Effective Rural Land Relations in Eastern Europe and Central Asia. Report No. 436. Washington: World Bank.

World Bank. 2000a. Natural Resource Management Strategy: Eastern Europe and Central Asia. Technical Paper No. 485. Washington: World Bank.

World Bank. 2000b. The State after Communism: Administrative Transitions in Central and Eastern Europe. Report No. 18779. Washington: World Bank.

World Bank. 2000c. Urban and Regional Dynamics in Poland. Policy Research Working Paper No. 2457. Washington: World Bank. 